\title{
Systematic Presentation of Ritz Variational Method for the Flexural Analysis of Simply Supported Rectangular Kirchhoff-Love Plates \\ Ike C. C.
}

Enugu State University of Science and Technology, P.M.B. 01660, Enugu, Nigeria

\section{Article info:}

Paper received:

The final version of the paper received:

Paper accepted online:
April 8, 2018

June 10, 2018

June 12, 2018
*Corresponding Author's Address: charles.ike@esut.edu.ng

\begin{abstract}
In this work, the Ritz variational method for solving the flexural problem of Kirchhoff-Love plates under transverse distributed load has been presented systematically in matrix form. An illustrative application of the matrix presentation was done for simply supported rectangular Kirchhoff-Love plate under uniformly distributed load. The application used a one term Ritz approximating displacement (coordinate, or basis) function. A one term Ritz approximate solutions obtained for center displacement of square plates showed a difference of $1.9 \%$ from the exact solution for displacement. Solution obtained for the bending moment at the center showed a difference of $7.9 \%$ from the exact solution for bending moment. The one term Ritz approximation for the maximum shear force showed a difference of $-10.7 \%$ from the exact solution. The results obtained for a one term Ritz approximation of the displacement shape function was reasonably close for practical purposes.
\end{abstract}

Keywords: Ritz variational method, Kirchhoff-Love plate, shape function, total potential energy, principle of minimization.

\section{Introduction}

Plates are three dimensional structures having one transverse dimension that is very small in comparison with the other (in-plane) dimension. They are usually subjected to forces applied perpendicularly to their plane. They therefore resist applied load by the development of bending moments in two in-plane directions, and a twisting moment. They can also be submitted to forces in the plane of the plate. They are thus commonly encountered structural forms used in floor slabs, bridge decks, foundations, and naval and aerospace structural panels.

The mathematical problems of plate analysis belongs to the three dimensional theory of elasticity governed by the simultaneous satisfaction of the requirements of the material stress-strain laws, the kinematic (geometric) relations between strain and displacements, the differential equations of equilibrium and the loading and restraint boundary conditions [1-4].

However, the full three dimensional theory of elasticity problem has often been approximated to two dimensional idealizations owing to the disparity in the scale of the dimensions, especially in thin plates. The analysis and theories of plates have been broadly categorized into two using the thickness to breadth ratios, namely thick plate theories (analysis) and thin plate theories (analysis). The ratio of the maximum deflection to the thickness has also been used as criterion in the classification of plates as plates with small deflection, and plates with large deflection.

This study uses the Kirchhoff-Love plate theory also called the classical thin plate theory. The Kirchhoff-Love plate theory, is based on three assumptions (Kirchhoff's hypothesis) which reduce the equations of the three dimensional theory of elasticity to two dimensions. They are [5-7]:

1. Cross-sections that are perpendicular to the neutral surface of the plate before bending remain straight and normal after bending deformation.

2 . The normal stress in the transverse (thickness) direction is so small as to be insignificant, and is neglected. Thus $\sigma_{z z}=0$. This simplifies the three dimensional stress-strain relations into a two dimensional problem.

3. The transverse shearing strains $\gamma_{x z}$ and $\gamma_{y z}$ are assumed to be zero. Thus the thickness of the plate does not change during flexural deformation.

Apart from the Kirchhoff-Love plate theory, other plate theories commonly used in the literature to analyse plates are: Mindlin plate theory [8], Reissner plate theory [9], Levinson plate theory, shear deformation plate theories, and Reddy's plate theory. 
Methods used in the analysis of plates are broadly classified as: analytical (or mathematical) methods, and numerical (or approximate) methods. The analytical methods, which seek to obtain closed form mathematical solutions to the plate problem at every point in the plate domain include: Eigen function expansion methods, integral transform methods, separation of variables methods, etc. The numerical methods seek to obtain approximate solutions to the plate problem. Some of the numerical methods are: variational methods [10], finite element methods, finite difference methods [11], finite grid methods, residual methods, and boundary collocation methods.

The research aim is to present systematically, the Ritz variational method for the flexural analysis of simply supported Kirchhoff plates under transverse distributed load. The objectives include:

a) to present the flexural problem of Kirchhoff plates under transverse distributed load as a variational problem, and state the problem in variational form;

b) to apply the principle of minimization of the total potential energy functional for the plate and find the equations of static equilibrium in equivalent variational form as the minimum total potential energy functional.

c) to find suitable coordinate shape functions for the simply supported ends of the plate.

\section{Research Methodology}

The total potential energy functional $\Pi$ of a Kirchhoff plate under distributed transverse load is the sum of the strain energy and the potential energy of the distributed load, and is given by the integral over the plate domain $R^{2}$ :

$\Pi=\iint_{R^{2}}\left\{\frac{D}{2}\left[\left(\nabla^{2} w\right)^{2}+2(1-\mu)\left(\frac{\partial^{2} w}{\partial x^{2}} \frac{\partial^{2} w}{\partial y^{2}}-\left(\frac{\partial^{2} w}{\partial x \partial y}\right)^{2}\right)\right]-q w\right\} d x d y$

where $w(x, y)$ - the deflection of the plate middle surface; $\mu$ - the Poisson's ratio of the plate; $D-$ the flexural rigidity of the plate; $q(x, y)$ - the intensity of distributed transverse load on the plate; $\nabla^{2}$ - the Laplacian operator in the $x-y$ coordinates; $R^{2}$ - the plate domain defined as 0 $\leq x \leq a, 0 \leq y \leq b$.

Let the deflection be approximated in terms of a linear combination of $\mathrm{n}$ basis (or coordinate or shape) functions of the space coordinates that apriori satisfy the end support conditions thus:

$$
\begin{gathered}
w_{n}(x, y)=\sum_{i=1}^{n} c_{i} \varphi_{i}(x, y) \\
w_{n}(x, y)=c_{1} \varphi_{1}(x, y)+c_{2} \varphi_{2}(x, y)+\ldots+c_{n} \varphi_{n}(x, y)
\end{gathered}
$$

where $c_{i}$ are the $n$ undetermined parameters of the displacement function $\varphi_{i}(x, y)$ are the coordinate, shape or basis functions that are chosen to satisfy the boundary conditions at the ends.

The total potential energy functional can be expressed in general as follows:

$$
\begin{aligned}
& \Pi=\iint_{R^{2}}\left\{\frac { D } { 2 } \left(\left(\nabla^{2} \sum_{i=1}^{n} c_{i} \varphi_{i}\right)^{2}+2(1-\mu)\left(\frac{\partial^{2}}{\partial x^{2}}\left(\sum_{i=1}^{n} c_{i} \varphi_{i}\right) \frac{\partial^{2}}{\partial y^{2}}\left(\sum_{i=1}^{n} c_{i} \varphi_{i}\right)-\right.\right.\right. \\
& \left.\left.\left.-\left(\frac{\partial^{2}}{\partial x \partial y} \sum_{i=1}^{n} c_{i} \varphi_{i}\right)^{2}\right)\right)-q \sum_{i=1}^{n} c_{i}\right\} d x d y
\end{aligned}
$$

where

$$
\begin{gathered}
\delta_{i k}=\delta_{k i}=\int_{0}^{a b} \int_{0}^{b} D\left\{\frac{\partial^{2} \varphi_{i}}{\partial x^{2}} \frac{\partial^{2} \varphi_{k}}{\partial x^{2}}+\frac{\partial^{2} \varphi_{i}}{\partial x^{2}} \frac{\partial^{2} \varphi_{k}}{\partial y^{2}}+\frac{\partial^{2} \varphi_{i}}{\partial y^{2}} \frac{\partial^{2} \varphi_{k}}{\partial x^{2}}+\frac{\partial^{2} \varphi_{i}}{\partial y^{2}} \frac{\partial^{2} \varphi_{k}}{\partial y^{2}}-\right. \\
\left.-(1-\mu)\left(\frac{\partial^{2} \varphi_{i}}{\partial x^{2}} \frac{\partial^{2} \varphi_{k}}{\partial y^{2}}+\frac{\partial^{2} \varphi_{i}}{\partial y^{2}} \frac{\partial^{2} \varphi_{k}}{\partial x^{2}}-2 \frac{\partial^{2} \varphi_{i}}{\partial x \partial y} \frac{\partial^{2} \varphi_{k}}{\partial x \partial y}\right)\right\} d x d y \\
\Delta_{i p}=\int_{0}^{a} \int_{0}^{b} q(x, y) \varphi_{i}(x, y) d x d y
\end{gathered}
$$

The principle of minimization of the total potential energy functional leads to the Ritz variational equation:

$$
\frac{\partial \Pi}{\partial c_{i}}=0
$$

for $i=1,2, \ldots, n$. In matrix form, the Ritz variational equations become the system of $n \times n$ equations in $c_{i}$ given by:

$$
\begin{aligned}
& \delta_{11} c_{1}+\delta_{12} c_{2}+\ldots+\delta_{1 n} c_{n}-\Delta_{1 p}=0 \\
& \delta_{21} c_{1}+\delta_{22} c_{2}+\ldots+\delta_{2 n} c_{n}-\Delta_{2 p}=0 \\
& \mathrm{M} \\
& \delta_{n 1} c_{1}+\delta_{n 2} c_{2}+\ldots+\delta_{n n} c_{n}-\Delta_{n p}=0
\end{aligned}
$$

or in matrix form,

$$
\left(\begin{array}{llll}
\delta_{11} & \delta_{12} & \mathrm{~L} & \delta_{1 n} \\
\delta_{21} & \delta_{22} & \mathrm{~L} & \delta_{2 n} \\
\mathrm{M} & & & \\
\delta_{n 1} & \delta_{n 2} & \mathrm{~L} & \delta_{n n}
\end{array}\right)\left(\begin{array}{l}
c_{1} \\
c_{2} \\
c_{n}
\end{array}\right)=\left(\begin{array}{c}
\Delta_{1 p} \\
\Delta_{2 p} \\
\\
\Delta_{n p}
\end{array}\right)
$$

A rectangular Kirchhoff-Love plate simply supported on the edges $x=0, x=a, y=0$, and $y=b$ and carrying uniformly distributed transverse load of intensity $q$ was considered in this study. A one unknown deflection parameter assumption was considered as the simplest case of representation of the deflection function given in general as the equation (2). Thus, $w(x, y)=c_{1} \varphi_{1}(x, y)$, $w(x, y)=c_{1} F_{1}(x) G_{1}(y)$, where $F_{1}(x)$ and $G_{1}(y)$ are the coordinate shape functions of the plate in the $x$ and $y$ coordinate directions respectively. The displacement and loading boundary conditions are:

$$
\begin{gathered}
F_{1}(x=0)=F_{1}(x=a)=0 \\
G_{1}(y=0)=G_{1}(y=b)=0 \\
\frac{\partial^{2}}{\partial x^{2}} F_{1}(x=0)=\frac{\partial^{2}}{\partial x^{2}} F_{1}(x=a)=0 \\
\frac{\partial^{2}}{\partial y^{2}} G_{1}(y=0)=\frac{\partial^{2}}{\partial y^{2}} G_{1}(y=b)=0
\end{gathered}
$$


Suitable coordinate (basis or shape) functions that satisfy the boundary conditions can be obtained using the polynomial shape functions as:

$$
\begin{aligned}
& F_{1}(x)=x^{4}-2 a x^{3}+a^{3} x \\
& G_{1}(y)=y^{4}-2 b y^{3}+b^{3} y
\end{aligned}
$$

The Ritz variational equation then simplifies to $\delta_{11} c_{1}=\Delta_{1 p}$, where

$\delta_{11}=D \int_{0}^{a} \int_{0}^{b}\left(\left(F_{1}^{\prime \prime}(x)\right)^{2}\left(G_{1}(y)\right)^{2}+2 F_{1}^{\prime \prime}(x) F_{1}(x) G_{1}^{\prime \prime}(y) G_{1}(y)+\left(F_{1}(x)\right)^{2} G_{1}^{\prime \prime}(y)\right.$

$-(1-\mu)\left(2 F_{1}^{\prime \prime}(x) F_{1}(x) G_{1}^{\prime \prime}(y) G_{1}(y)-2\left(F_{1}^{\prime}(x)\right)^{2}\left(G_{1}^{\prime}(y)^{2}\right)\right) d x d y$

where

$$
\begin{gathered}
F_{1}^{\prime \prime}(x)=\frac{d^{2} F_{2}(x)}{d x^{2}} \\
G_{1}^{\prime}(y)=\frac{d G_{1}(y)}{d y^{2}} \\
G_{1}^{\prime \prime}(y)=\frac{d^{2} G_{1}(y)}{d y^{2}} \\
\Delta_{1 p}=\int_{0}^{a b} \int_{0}^{b} q F_{1}(x) G_{1}(y) d x d y
\end{gathered}
$$

By differentiation,

$$
\begin{gathered}
F_{1}^{\prime}(x)=4 x^{3}-6 a x^{2}+a^{3} \\
F_{1}^{\prime \prime}(x)=12 x^{2}-12 a x=12\left(x^{2}-a x\right) \\
G_{1}^{\prime}(y)=4 y^{3}-6 b y^{2}+b^{3} \\
G_{1}^{\prime \prime}(y)=12 y^{2}-12 b y=12\left(y^{2}-b y\right) \\
\delta_{11}=D\left\{\int_{0}^{a}\left(F_{1}^{\prime \prime}(x)\right)^{2} d x \int_{0}^{b}\left(G_{1}(y)\right)^{2} d y+2 \int_{0}^{a} F_{1}^{\prime \prime}(x) F_{1}(x) d x \int_{0}^{b} G_{1}^{\prime \prime}(y) G_{1}(y) d y\right. \\
+\int_{0}^{a}\left(F_{1}(x)\right)^{2} d x \int_{0}^{b}\left(G_{1}^{\prime \prime}(y)\right)^{2} d y-2(1-\mu)\left(\int_{0}^{a} F_{1}^{\prime \prime}(x) F_{1}(x) d x \int_{0}^{b} G_{1}^{\prime \prime}(y) G_{1}(y) d y\right. \\
\left.\left.-\int_{0}^{a}\left(F_{1}^{\prime}(x)\right)^{2} d x \int_{0}^{b}\left(G_{1}^{\prime}(y)\right)^{2} d y\right)\right\} \\
\Delta_{1 p}=q \int_{0}^{a} F_{1}(x) d x \int_{0}^{b} G_{1}(y) d y \\
\delta_{11}=D\left\{I_{1} I_{2}+2 I_{3} I_{4}+I_{5} I_{6}-2(1-\mu)\left(I_{3} I_{4}-I_{7} I_{8}\right)\right\} \\
\Delta_{1 p}=q I_{9} I_{10}
\end{gathered}
$$

where

$$
\begin{aligned}
I_{1}=\int_{0}^{a}\left(F_{1}^{\prime \prime}(x)\right)^{2} d x & I_{2}=\int_{0}^{b}\left(G_{1}(y)\right)^{2} d y & I_{3}=\int_{0}^{a} F_{1}^{\prime \prime}(x) F_{1}(x) d x \\
I_{4}=\int_{0}^{b} G_{1}^{\prime \prime}(y) G_{1}(y) d y & I_{5}=\int_{0}^{a}\left(F_{1}(x)\right)^{2} d x & I_{6}=\int_{0}^{b}\left(G_{1}^{\prime \prime}(y)\right)^{2} d y \\
I_{7}=\int_{0}^{a}\left(F_{1}^{\prime}(x)\right)^{2} d x & I_{8}=\int_{0}^{b}\left(G_{1}^{\prime}(y)\right)^{2} d y & I_{9}=\int_{0}^{a} F_{1}(x) d x \\
I_{10} & =\int_{0}^{b} G_{1}(y) d y &
\end{aligned}
$$

The integrals are evaluated to yield:

$$
\begin{gathered}
I_{1}=\int_{0}^{a}\left(F_{1}^{\prime \prime}(x)\right)^{2} d x=\frac{24}{5} a^{5} \quad I_{2}=\frac{31}{630} b^{9} \quad I_{3}=-\frac{17}{35} a^{7} \\
I_{4}=-\frac{17}{35} b^{7} \quad I_{5}=\frac{31}{630} a^{9} \quad I_{6}=\frac{24}{5} b^{5} \quad I_{7}=\frac{17}{35} a^{7} \\
I_{8}=\frac{17}{35} b^{7} \quad I_{9}=\frac{a^{5}}{5} \quad I_{10}=\frac{b^{5}}{5}
\end{gathered}
$$

Hence,

$$
\begin{gathered}
\delta_{11}=D\left(\frac{744 a^{5} b^{9}}{3150}+\frac{744}{3150} a^{9} b^{5}+\frac{578 a^{7} b^{7}}{1225}\right) \\
\Delta_{11}=\frac{1}{25} q a^{5} b^{5} \quad c_{1}=F \frac{q}{D} \\
F=\left(\frac{744}{126}\left(b^{4}+a^{4}\right)+\frac{578}{49} a^{2} b^{2}\right)^{-1} \\
w_{1}(x, y)=\frac{F q}{D}\left(x^{4}-2 a x^{3}+a^{3} x\right)\left(y^{4}-2 b y^{3}+b^{3} y\right)
\end{gathered}
$$

Deflection at the centre $(x=a / 2 ; y=b / 2)$ :

$$
w_{c}=\frac{25}{256}\left(\frac{744}{126}\left(1+\alpha^{4}\right)+\frac{578}{49} \alpha^{2}\right)^{-1} \frac{q a^{4}}{D}
$$

where $\alpha=a / b$.

\section{Results}

\subsection{Square Kirchhoff-Love plates}

For square Kirchhoff-Love plates, $a=b, \alpha=1$ :

$$
\begin{gathered}
\delta_{11}=0.944 D a^{14} ; \quad \Delta_{1 p}=\frac{q a^{10}}{25} ; \\
c_{1}=0.0378 \frac{q a^{4}}{D} ; \quad w_{c}=0.004 \frac{q a^{4}}{D} .
\end{gathered}
$$

\subsection{Bending moment and shear force}

Using the bending moment-deflection relations and the shear deflection relations, the maximum bending moments occur at the plate centre, and is given for square plates by:

$$
M_{x x}=0.0517 q a^{2} .
$$

The exact solutions obtained by Timoshenko and Woinowsky-Krieger [12] is:

$$
M_{x x_{\max }}=0.0479 q a^{2} .
$$

Similarly,

$$
Q_{x}=0.420 q a
$$




\section{Discussion}

The Ritz variational method which is based on the principle of minimization of the total potential energy functional for a structure has been presented in a systematic way for the flexural problem of Kirchhoff-Love plates under distributed load. The presentation relied on the approximation of the unknown deflection function $w(x, y)$ using approximating displacement shape functions with unknown displacement parameters, and constructed from basis (shape) functions that satisfied apriori the boundary conditions of the loading and the deformation. This yielded the total potential energy functional given in general as equation (3). Application of the extremum condition gave the system characteristic equations in matrix form as equation (8). The use of the method was illustrated for rectangular Kirchhoff-Love plates with simply supported edges using a one term displacement approximation. For a square thin plate, the centre deflection was obtained as equation (10) giving a relative error of $1.9 \%$ The bending moment at the centre was obtained using the bending moment-deflection relations as equation (11) giving a relative error of $7.9 \%$. The maximum shear force was obtained from the shear force-deflection relation as equation (13), giving a relative error of $-10.7 \%$.

\section{Conclusions}

The following conclusions are made from this study.

1. The Ritz variational method can be presented in systematic form using matrices in a displacement based procedure.

2. The stiffness influence coefficients are determined from the shape function by integration.

3 . The unknown displacement parameters of the deflection function are evaluated by solving the matrix algebraic equation.

4. A one unknown parameter choice of the deflection function that satisfied the geometric and force boundary conditions yielded seasonally accurate prediction of the maximum deflection at the center with a relative error of $1.9 \%$. This is reasonable considering the ease of computation offered by the method.

5. A one parameter choice of the deflection function that satisfied the natural and force boundary conditions was less accurate in the estimation of the maximum bending moments and shear force, yielding relative errors of $7.9 \%$ for maximum bending moment and $-10.7 \%$ for the shear force.

\section{References}

1. Ike, C. C., Nwoji, C. U., Ikwueze, E. U., \& Ofondu, I. O. (2017). Bending analysis of simply supported Kirchhoff plates under linearly distributed transverse load. Explorematics Journal of Innovative Engineering and Technology, Vol. 1, No. 1, pp. 28-36.

2. Ike, C. C., Nwoji, C. U., \& Ofondu, I. O. (2017). Variational formulation of Mindlin plate equation and solution for deflection of clamped Mindlin plates. International Journal for Research in Applied Sciences and Engineering, Vol. 5, Issue 1, pp. 340-353.

3. Nwoji, C. U., Onah, H. N., Mama B. O., \& Ike, C. C. (2017). Theory of elasticity formulation of Mindlin plate equations. International Journal of Engineering and Technology, Vol. 9, No. 6, pp. 4344-4352, doi: 10.21817/ijet/2017/v9i6/170906074.

4. Ike, C. C. (2017). Equilibrium method in the derivation of differential equations for homogeneous isotropic Mindlin plates. $N i$ gerian Journal of Technology, Vol. 36, No. 2, pp. 346-350.

5. Ike, C. C. (2017). Kantorovich Euler-Lagrange-Galerkin method for bending analysis of thin plates. Nigerian Journal of Technology, Vol. 36, No. 2, pp. 351-360.

6. Mama, B. O., Nwoji, C. U., Ike, C. C., \& Onah, H. N. (2017). Analysis of simply supported rectangular Kirchhoff plates by the finite Fourier sine transformation method. International Journal of Advanced Engineering Research, Vol. 4, Issue 3, pp. 285291.

7. Nwoji, C. U., Mama, B. O., Ike, C. C., \& Onah, H. N. (2017). Galerkin-Vlasov method for the flexural analysis of rectangular Kirchhoff plates with clamped and simply supported edges. IOSR Journal of Mechanical and Civil Engineering, Vol. 14, Issue 2, pp. 61-74, doi: 10.9790/1654-1402.16174.

8. Mindlin, R. D. (1951). Influence of rotary inertia and shear on flexural motions of isotropic elastic plates. Journal of Applied Mechanics, Vol. 18, No. 1, pp. 31-38.

9. Reissner, E. (1945). The effect of transverse shear deformation on the bending of elastic plates. Journal of Applied Mechanics, Vol. 12, pp. 69-77.

10. Aginam, C. H., Chidolue, C. A., \& Ezeagu, C. A. (2012). Application of direct variational method in the analysis of isotropic thin rectangular plates. ARPN Journal of Engineering and Applied Sciences, Vol. 7, No. 9, pp. 1128-1138.

11. Eze, J. C., Ibearugbulem, O. M., \& Onyechere, C. I. (2013). Pure bending analysis of thin rectangular flat plates using ordinary finite difference method. International Journal of Emerging Technology and Advanced Engineering, Vol. 3, Issue 3, pp. 20-23.

12. Timoshenko, S., \& Woinowsky-Krieger (1959). Theory of plates and shells. McGraw Hill, Tokyo. 


\title{
Систематичне викладення варіаційного методу Рітца для аналізу жорсткості шарнірно опертої прямокутної пластини Кірхгофа-Лява
}

\author{
Іке Ч. Ч.
}

\author{
Державний університет науки і технології м. Енугу , П.М.Б. 01660, м. Енугу, Нігерія
}

\begin{abstract}
Анотація. У роботі у матричній формі представлений узагальнений спосіб застосування варіаційного метода Рітца для розв'язання задачі про вигин навантаженої пластини Кірхгофа-Лява. Наведено приклади застосування шарнірно опертої прямокутної пластини під рівномірно розподіленим навантаженням, використовуючи функції форми у базисі прямокутної системи координат. Один з прикладів наближеного розв'язку за методом Рітца отримано для переміщення центра квадратної пластини плит. При цьому, відносна похибка відносно точного значення складає $1,9 \%$. Отримане значення для згинального моменту у центрі пластини відрізняється від існуючого точного рішення на 7,9\%. Значення перерізувального зусилля дає похибку

$-10,7 \%$. Таким чином, одержані результати для апроксимації функції форми із подальшим застосуванням методу Рітца, є достатньо близькими для практичних цілей.
\end{abstract}

Ключові слова: варіаційний метод Рітца, пластина Кірхгофа-Лява, функція форми, загальна потенціальна енергія, принцип мінімізації. 